\title{
Correction: Heme Oxygenase 1 in Vertebrates: Friend and Foe
}

\author{
Rafael Cardoso Maciel Costa Silva $\mathbb{B}^{1} \cdot$ Leonardo Holanda Travassos Correa ${ }^{1}$
}

Published online: 6 December 2021

(c) Springer Science+Business Media, LLC, part of Springer Nature 2021

Correction to: Cell Biochemistry and Biophysics

$$
\text { https://doi.org/10.1007/s12013-021-01047-z }
$$

In the version of this article initially published, the reference number 17 is cited as "Alam J, Cook JL. Transcriptional regulation of the heme oxygenase- 1 gene via the stress response element pathway. Curr Pharm Des. 2003;9 (30):2499-511. https://doi.org/10.2174/1381612033453730. PMID: 14529549" but it should be cited as:
“Alam J, Cook JL. How many transcription factors does it take to turn on the heme oxygenase-1 gene? Am J Respir Cell Mol Biol. 2007 Feb;36(2):166-74. https://doi. org/10.1165/rcmb.2006-0340TR. Epub 2006 Sep 21. PMID: 16990612". The original article has been corrected.
Rafael Cardoso Maciel Costa Silva

rcmcs@biof.ufrj.br

Laboratory of Immunoreceptors and Signaling, Instituto de Biofísica Carlos Chagas Filho, Federal University of Rio de Janeiro, Rio de Janeiro, Brazil 